Federal Reserve Bank of Minneapolis

Research Department

\title{
New Evidence on State Banking Before the Civil War*
}

\author{
Warren E. Weber \\ Working Paper 642
}

Revised July 2006

Preliminary and incomplete

Note: Chart intended to be printed in color

\begin{abstract}
Prior to the Civil War there were three major differences among states in how U.S. banks were regulated: (1) Whether they were established by charter or under free-banking laws. (2) Whether they were permitted to branch. (3) Whether the state established a state-owned bank. I use a census of the state banks that existed in the United States prior to the Civil War that I recently constructed to determine how these differences in state regulation affected the banking outcomes in these states. Specifically, I determine differences in banks per capita by state over time; bank longevities (survival rates) by state, size, and type of organization; and bank failure probabilities also by state, size, and type of organization. In addition, I estimate the losses experienced by note holders and determine whether there were systematic differences in these depending on whether or not a bank was organized under a free banking law.
\end{abstract}

* The views expressed herein are those of the author and not necessarily those of the Federal Reserve Bank of Minneapolis or the Federal Reserve System. 
Prior to the Civil War, banks in the United States were regulated by the individual states in which they were located. However, state attitudes toward banking and state regulation of banking were not uniform across states. These differences in regulatory structures makes this period a good laboratory in which to examine banking outcomes under various regulatory structures.

There were three major differences in state banking regulation during this period. The first is the process that individuals had to follow to establish a bank. The majority of banks that went into business did so under a state charter, a specific law that permitted the establishment of the bank subject to conditions on how that bank could operate. However, during some times in some states individuals could establish a bank without a charter if they abided by general banking laws (so-called "free banking laws") that also placed restrictions on how the bank could operate. ${ }^{1}$ The major difference between these two regulatory structures was that banks operating under charters generally could issue notes against any of their assets whereas those operating under general banking laws were required to collateralize their note issue with state bonds deposited with a state authority.

The second major difference among states in terms of regulations was whether banks were permitted to operate branches within the state or whether they were restricted to operate in a single location. The third major difference was whether or not banking in the state was a monopoly or close to a monopoly. Generally, if the state had a monopoly bank, a large portion of the stock of that bank was owned by the state.

Recently, I have constructed a census of the state banks that existed in the United States prior to the Civil War. This data set is a compilation of the names and locations

\footnotetext{
${ }^{1}$ Thus, the "free" in free banking refers to free entry into banking, not to laissez-faire banking.
} 
of all banks that existed between 1782-1861, an estimate of the date at which each began business, and an estimate of the date at which a bank went out of business if it was not in business on December 31, 1860. The identification of banks and the estimates of their period of operation are based primarily on when they were listed in published bank balance sheets or in banknote reporters. In addition, I have compiled a data set of 26,000 individual balance sheets for banks during this period. These data are available on my website. In this paper, I use these data sets to determine how banking outcomes differed depending on the regulatory regime.

To examine the effects of differences in bank regulation, first I divide banks into four categories: 1) State chartered banks that did not branch or branched to only a limited extent, 2) State chartered banks with extensive branching, 3) Free banks, and 4) State monopoly or state owned branch banking systems. These classifications and some clarification are provided in the next section.

For each of the four categories of banks, I determine the following banking outcomes: First, the average size of banks. This is done is section 2. Second, the success of the system as measured by bank longevities (survival rates) and failure rates. This is done is section 3 . Third, the losses experienced by note holders when banks failed. This is done in section 4 . The final section is a summary.

\section{Classification of banks}

In general, it is straightforward to assign a bank to one the four categories I am considering. However, there are some cases that have to be discussed.

The first has to do with banks in Connecticut. Three Connecticut banks had a single 
branch each. However, for two of these, the branch was in existence for only part of the bank's life. Therefore, I only count one of these, the Phoenix Bank, Hartford, as being a chartered bank with branches. In addition, Connecticut passed a free banking law on June 25, 1852. Fourteen banks were established under this law. However, the law was repealed on June 30, 1855, and all of these banks converted to chartered banks. Because the free banking law was in effect for such a short time and because all of these banks were still in existence on January 1, 1861, I classify them as chartered banks rather than free banks.

Similar issues occur with regard to New York banks. Five New York banks had branches, but for two of these banks, the branches were only in existence for a short period of time. A third closed its branch when it converted to a free bank. Thus, I only count two banks, the Bank of Hudson and the Ontario Bank, as having branches. With regard to chartered versus free banks, New York did not charter any new banks after the passage of its free banking legislation on April 18, 1838. Further, if the charter of an existing bank expired after that date, it had to convert to a free bank to continue operating. Overall, 46 banks that began as chartered banks ended up as free banks, and I classify them as such.

An issue also arises with regard to the State Bank of Ohio. The banks that were part of this system were called branches. However, each was separately and privately organized and operated independently. For this reason I consider each of these branches to be an individual chartered bank.

The final classification issue is which banks should be considered state monopoly or state owned branch banking systems. I use two criteria to put a bank in this category. The first is that a substantial portion of the capital of the bank be subscribed by the state. The second is that it be the only (or almost the only) bank in the state for a substantial period 
of time. The 17 banks I put in this category are listed in Appendix Table A1.

In Table 1, I present my classification of banks by type and state. The table shows that the largest number of banks that existed during this period were chartered banks that did not branch. Further, this was the predominant form of bank organization in all of the New England states, all of the mid-Atlantic states with the exception of New York, several states in the deep South, Ohio, Kansas, and Nebraska, meaning that it was the predominant form of bank organization in slightly more than half of the states. Overall, 31 states had at least one bank of this type.

The table shows that chartered banks with branches were relatively uncommon. I count only 54 such banks out of the 2332 that existed at one time or another. Only 14 states had banks with branches, and the vast majority of these were located in the South.

Table 1 shows that while there were a large number of free banks (897), these were concentrated in only eight states - New York, New Jersey, and six states in the West. Further, the table shows that roughly two-thirds of the states had no free banking.

Finally, there were 17 banks that had state monopolies. They existed almost exclusively in the South and West. A list is given in the Appendix.

\section{Size of banks}

Tables 2 through 4 contain information on the size of banks by category. I use three measures of size in these tables - average total assets, average capital, and average circulation. The calculations in these tables are based on the extensive balance sheet information for banks during this period that I have compiled. ${ }^{2}$ It should be noted that because balance

\footnotetext{
${ }^{2}$ This information is available on my website.
} 
sheet information is not available for all banks, these tables are based on information for only 2130 banks.

These tables clearly show that largest banks were the state monopoly banking systems. On average, these banks had total assets slightly over $\$ 4$ million, capital close to $\$ 1.7$ million, and circulation close to $\$ 1.4$ million. Further, with the exception of the Louisiana State Bank and the Bank of the State of Arkansas, on a state-by-state comparison, state monopoly banks were larger than the average size of banks in any of the other three categories.

The next largest banks were the chartered banks that were permitted to branch. On average, these banks had total assets of $\$ 2.8$ million, capital over $\$ 1.1$ million, and circulation close to $\$ 750,000$. Further, on a state-by-state comparison, chartered banks that were permitted to branch were larger than chartered banks that could not branch and free banks. The third largest category of banks by size were the chartered banks that could not branch. On average, these banks had total assets slightly over $\$ 500,000$, capital slightly over $\$ 250,000$, and circulation slightly over $\$ 125,000$. Further, on a state-by-state comparison, charter banks were slightly larger than free banks in those states that had banks operate under both systems. However, there were some exceptions. Illinois free banks were larger on average than its chartered banks; Massachusetts free banks, of which there were only four all located near Boston, were larger than the average chartered bank in that state; and Vermont's single free bank, the South Royalton Bank was slightly larger than the average chartered bank in that state. Further, the two free banks in Tennessee were slightly larger in terms of capital and circulation, but not total assets, than the average chartered bank in that state.

Free banks were the smaller category of banks by size. On average, these banks had 
total assets slightly under $\$ 400,000$, capital slightly over $\$ 150,000$, and circulation slightly over $\$ 75,000$.

\section{Success}

In this section, I examine the success of these categories of banking organization. I use two measures of success. The first is the survival probabilities of banks. The second is the failure rates.

\section{A. Survival rates}

The overall survival probabilities for the various categories of banks are given in Figures 1a and $1 b{ }^{3}$ Figure 1a shows the survival probability over the entire range of possible longevities, which is slightly less than 79 years, since the first bank in the United States, the Bank of North American in Philadelphia, began operations on March 26, 1782 and the sample ends on December 31, 1860. Since most of the action in the survival probabilities is in the first 10 years of existence, these probabilities are shown separately in Figure 1b. Survival probabilities by state for selected longevities are also given in Tables 5 through 8 . The figures and tables show that the survival probabilities were the highest for chartered banks with branches followed by those for chartered banks. Survival rates for free banks were much lower, and the survival probabilities for state monopoly banks were somewhere in between.

Considering all chartered banks with and without branches, the probability that a bank would survive 5 years was 0.88 for banks with branches and 0.82 for banks without

\footnotetext{
${ }^{3}$ The survival probablities are computed by the method given in Kiefer (1988). The maximum length of time that banks of a particular type could have been in existence is taken to be the time at which the first bank of the type began until December 31, 1860. For this reason, not all of the lines in Figure 1a extend for the full 79 years. Similarly, the maximum length of time that banks of a particular type in a state could have been in existence is taken to be the time at which the first bank of the type began in the state until December 31, 1860. This gives rise to the blanks in Tables 5 through 8.
} 
branches. The chances of either type of bank surviving 10 years was better than 7 out of 10 and there were slightly better than even odds that banks of these types would survive 30 years.

However, the difference between the two categories of banks is sharper if one does a state-by-state comparison. Comparing the survival probabilities of chartered banks with and without branches for the 7 states (those listed as having primarily charted banks with branches in Table 1) with large numbers of both shows that the survival probabilities are markedly higher for the banks with branches that for the banks without. Thus, the reason that the survival probabilities are much closer for the two types of banks when all banks are considered than for a state-by-state comparison is that there were several states - most notably, Connecticut, Pennsylvania, Rhode Island, and South Carolina - that had large numbers of chartered banks without branches with very high survival probabilities

Free banks had much lower survival probabilities, at least if one considers the probability of a bank surviving 40 or more years. ${ }^{4}$ In fact, free banks had only a 0.87 probability of surviving 1 year, and that probability fell to 0.62 for such a bank to survive for 5 years. There was only a 50/50 chance that a free bank would survive for 10 years or more. Further, a stateby-state comparison of free banks and chartered banks without branches is only somewhat more favorable to free banks. In New York, the survival probabilities for chartered banks without branches and free banks are roughly similar. However, for the two other states with large numbers of both types of banks - Michigan and New Jersey - the survival probabilities

\footnotetext{
${ }^{4}$ Since the first free banking act was not passed until March 15, 1837, by the state of Michigan, it may strange that there are free banks that were in existence for more than 23 years. The reason is that New York banks that began as chartered banks, but that had to become free banks when their charters expired are counted as free banks for the reasons given in Section 1.
} 
for free banks were markedly lower than those of the chartered banks without branches.

State monopoly banks had survival probabilities somewhere in between these other categories of banks. In fact, all 17 state monopoly banks lasted at least 1.99 years, and they had a 0.94 probability of lasting at least 5 years. However, the probability that a state monopoly banks would survive 7 years or more was similar to that of a free bank, and the probability that a state monopoly bank would survive 15 or more years was markedly below that of the other categories of banks.

Looking at the individual states gives a slightly different picture, however. Unlike other types of banks, all state monopoly banks survived at least one year, and with the exception of Iowa and Illinois, state monopoly banks had a probability of 1 of surviving at least 5 years.

\section{B. Failure rates}

The second measure of the success of banks by category is their failure rates. My definition of a bank failure is that used by Rolnick and Weber (1983), which is that bank is said to fail if it went out of business and there were losses to noteholders. A bank is considered to have closed if it went out of business, but noteholders were paid the full nominal value of their notes. The justification for this definition is that "a major intent of the free banking laws was to provide a safe currency." (Rolnick and Weber, 1983, page 1084)

I determined whether a bank that went out of business closed or failed using three sources:

1. Congressional documents. For many free banks that went out of business, the rates at which their notes were redeemed by state banking authorities were given in various 
Congressional documents. Banks were considered to have failed if their notes were redeemed at less than dollar-for-dollar. Banks were considered to have closed if their notes were redeemed at par or a bond was posted for the redemption of notes. I classified 64 banks as failures by this method.

2. Banknote reporters for New York and Philadelphia. In examining various banknote reporters, I found that when banks were explicitly listed as "failed," the discounts on their notes were higher than those of other banks in the city or state. However, in those cases when banks were explicitly listed as "closed," the discounts on their notes were the same as those of other banks in the city or state. Therefore, I concluded that in other cases when I knew a bank had gone out of business and its notes where listed at a discount higher than other banks, it too had failed. I classified an additional 129 banks as failures in this way.

3. Secondary sources. Bryan (1899), Root (1901), Stackpole (1900), and Walsh (1940) contain discussions that led me to conclude that 35 more banks failed. The remaining 184 bank failures were designated as such based in the designation in Haxby (1988). Since Haxby's definition of a failure may have been broader than mine, in the sense that a bank was classified as having failed if any creditor or shareholder suffered a loss, some of these banks may have actually closed in my sense of the term. That this may be the case is suggested by the fact that I have found several cases in which Haxby designates a bank as having failed but the discounts would indicate that the bank closed instead. Nonetheless, I followed Haxby's designation in these cases.

A listing of bank failures by state is given by category in Tables 9 through 12 . In the 
tables, states are listed in ascending order of the probability that a bank failed in the state.

An examination of the failure probabilities in these tables gives a different picture of the successfulness of these various types of banking organizations. Now it is free banks that have the lowest failure probabilities (15.5 percent). Next are charter banks, both with and without branches, with virtually identical failure probabilities of about 22 percent. State monopoly banks had the highest failure probability, nearly 30 percent.

One might object that the failure probabilities for free banks are biased downward by the fact that I did not consider what happened to banks after the end of 1860 and a great many of the failures in Illinois and Wisconsin occurred in 1861. In fact, 26 banks failed in Illinois and 36 banks failed in Wisconsin in 1861. Counting these as free bank failures would raise the failure percentage from 15.1 percent to 21.7 percent, virtually the same as that for chartered banks without branches.

The column labeled "Good (\%)" shows that chartered and free banks had roughly a 0.6 probability of staying in business throughout the period. However, if a charter or free bank went out of business, it was more likely to have failed if it was a chartered bank (approximately a 0.55 probability) than if it was a free bank (approximately a 0.4 probability). There are two possible reasons why this could have been the case. One is that since chartered banks could back their note issue with any assets rather than being required to back them with state bonds, the backing for their notes was riskier and hence noteholders losses were more likely. The other is that when state bond prices fell, free bankers found it more profitable to close their doors than to provide more capital to purchase the additional bonds necessary to support their note circulation. The state monopoly banks exhibited very different outcomes. They had only about a 0.3 probability of staying in business throughout the period, although 
when they went out of business, their probability of failure was 0.4 , about the same as free banks.

\section{Noteholder losses}

The final type of bank outcome that I consider is the losses experienced by noteholders when banks failed. Estimates of these losses are presented in Table 13. The table contains information on the number of banks on which the estimate is based ("Number of banks"). It also contains the average over these banks of (i) the last reported circulation in their balance sheets ("Average circulation/bank"), (ii) their last circulation multiplied by one minus the rate at which their notes were redeemed after failure ("Average loss/bank"), and (iii) the ratio of these last two items ("Average loss/dollar).

The panels in the table differ by the way in which I determine the rate at which the notes of failed banks were redeemed. In the uppermost panel, entitled "Losses based on redemption rates," the redemption rates for notes of chartered banks are taken almost exclusively from Root (1901). (The last circulation before failure for these banks also comes from Root rather than from the last balance sheet.) I have been unable to obtain noteholder loss information for other chartered banks. This means that the sample of banks is small, only 23 out of the 262 chartered banks that failed, and limited to banks in New England. The failed free banks in the sample for this panel are only those from Indiana, Illinois, Minnesota, New York, and Wisconsin. The redemption rates are those at which the state banking authorities redeemed the notes after a bank failed. Here the coverage is better; the sample contains 60 out of the 131 failures. ${ }^{5}$ Note that I with this method, I am unable to obtain any estimates

\footnotetext{
${ }^{5}$ Note that there are two reasons why a bank might not appear in any of the samples in this table. One is that I am unable to obtain redemption information for the bank. The other is that I have been unable to
} 
of noteholder losses due to the failure of chartered banks with branches or state monopoly banks.

The second and third panels of the table use bank discounts rather than redemption rate information to estimate noteholder losses. In other words, in these panels, losses per bank are obtained by multiplying the bank's last reported circulation by the reported discount on its notes subsequent to failure. ${ }^{6}$ In the second panel, the discounts used are those in New York; in the third panel, those in Philadelphia. These discounts are taken from banknote reporters in these two cities

The second and third panels are divided into two subpanels, the top one of which contains at least as many banks as the bottom one. The difference concerned the treatment of banks that disappeared from the banknote reporter after the bank failed. In the top subpanel, these banks are treated as having redemption rates of zero; that is, they are include in the sample with all of their notes being treated as if they were totally worthless after failure. In the bottom panel, such banks are dropped from the sample.

There are three points of note in the table. The first is that the average circulation per failed bank is smaller than the average circulation for all banks for a given type. One could take this as suggesting that small banks were more likely to fail than large banks. However, such an argument is not consistent with the finding mentioned above that failure rates did not vary much by type of bank even though there were large size differences. A more reasonable argument is that banks ran down their circulation, either voluntarily or involuntarily, prior

obtain any balance sheet information for the bank. Although I have been able to obtain at least one balance sheet for 2130 banks, I have only been able to do so for xxx of the xxx banks that failed.

${ }^{6}$ In actuality, I also adjust this discount to account for the discount on the notes of banks in the same location (city, if possible, or else state) that continued in business. 
to failure.

The second point to note in the table is that the estimated average loss per dollar are similar across the different methods of estimating them.

The third and most interesting point to note in the table is that the average loss per dollar on the notes of free banks was always less than the loss per dollar on the notes of charter banks both with and without branches. This could be related to the possibility mentioned that above that because chartered banks could back their note issue with any assets rather than being required to back them with state bonds, the backing for their notes was riskier and hence noteholders losses were larger when chartered banks failed.

\section{Summary}

In this paper I examined how state banks organized under four different types of regulation fared during the period prior to the Civil War The four different types of banking organizations were chartered banks without branches, chartered banks with branches, free banks, and state monopoly banks. This examination yielded three major findings:

1. On average, chartered banks and state monopoly banks were the largest, followed by chartered banks. Free banks were the smallest.

2. Although the survival probabilities of the various types of banks were correlated with size over the short term, chartered banks and free banks had roughly the same survival rates over the long run. State monopoly banks had the lowest long run survival rates.

3. Free banks had the lowest failure rates of the four types of banks, followed by chartered banks. State monopoly banks had the highest failure rates.

4. Not only did free banks have the lowest failure rates, they also had the lower noteholder 
losses in terms of dollars/note when a bank failed than did chartered banks. This suggests that free banking laws did in fact help protect noteholders from loss as was one of the intentions of these laws. 


\section{References}

Bryan, Alfred C. 1899. History of state banking in Maryland. Baltimore: Johns Hopkins Press.

Haxby, James A. 1988. Standard catalog of United States obsolete bank notes, 1782-1866. Iola, WI: Krause Publications.

Kiefer, Nicolas M. 1988. Economic duration data and hazard functions. Journal of Economic Literature 26 (June): 646-79.

Rolnick, Arthur J., Weber, Warren E. 1983. New evidence on the Free Banking Era. American Economic Review xx (December): 1080-91.

Root, L. Carroll. 1901. Twenty years of bank currency based on general commercial assets. Sound Currency 8 (December): 209-32.

Stackpole, Everett Birney. 1900. State banking in Maine. Sound Currency 7 (May): 57-88.

Walsh, John J. 1940. Early banks in the District of Columbia: 1792-1818. Washington, DC: Catholic University of America Press.

Weber, Warren E. 2003. Interbank payments relationships in the antebellum United States: Evidence from Pennsylvania. Journal of Monetary Economics 50: 455-74. 
Table 1: Number of banks by type and state

States with primarily chartered banks without branches

\begin{tabular}{lrrrr}
\multicolumn{1}{c}{ State } & $\begin{array}{r}\text { Charteredl } \\
\text { no branches }\end{array}$ & $\begin{array}{r}\text { Charteredl } \\
\text { branches }\end{array}$ & Free & $\begin{array}{r}\text { State } \\
\text { monopoly }\end{array}$ \\
\hline Alabama & 10 & 1 & 1 & 1 \\
Connecticut & 82 & 1 & & \\
Delaware & 10 & & & \\
District of Columbia & 21 & & & \\
Florida & 14 & & & \\
Kansas & 1 & & & \\
Louisiana & 24 & & & \\
Maine & 124 & & & \\
Maryland & 54 & & 26 & \\
Massachusetts & 225 & & 14 & \\
Nebraska & 8 & & & \\
New Hampshire & 69 & & & \\
New Jersey & 70 & & & \\
Ohio & 110 & & & \\
Pennsylvania & 114 & & & \\
Rhode Island & 104 & 19 & &
\end{tabular}

States with primarily chartered banks with branches

\begin{tabular}{lrrrr}
\multicolumn{1}{c}{ State } & $\begin{array}{r}\text { Charteredl } \\
\text { no branches }\end{array}$ & $\begin{array}{r}\text { Chartered } \\
\text { branches }\end{array}$ & Free & $\begin{array}{c}\text { State } \\
\text { monopoly }\end{array}$ \\
\hline Georgia & 46 & 7 & & 3 \\
Kentucky & 20 & 5 & & 1 \\
Mississippi & 21 & 5 & & 1 \\
Missouri & 4 & 7 & & \\
North Carolina & 11 & 5 & 2 & \\
Tennessee & 34 & 8 & & \\
Virginia & 23 & 7 &
\end{tabular}

States with primarily free banks

\begin{tabular}{lrrrr}
\multicolumn{1}{c}{ State } & $\begin{array}{r}\text { Chartered/ } \\
\text { no branches }\end{array}$ & $\begin{array}{c}\text { Chartered/ } \\
\text { branches }\end{array}$ & Free & $\begin{array}{c}\text { State } \\
\text { monopoly }\end{array}$ \\
\hline Indiana & 2 & & 96 & 2 \\
Illinois & 3 & & 131 & 5 \\
Michigan & 30 & 3 & 38 & \\
Minnesota & & & 16 & \\
New York & 61 & 2 & 423 & \\
Wisconsin & 3 & & 142 &
\end{tabular}

States with primarily state monopoly banks

\begin{tabular}{|c|c|c|c|c|}
\hline State & $\begin{array}{c}\text { Charteredl } \\
\text { no branches }\end{array}$ & $\begin{array}{r}\text { Chartered/ } \\
\text { branches }\end{array}$ & Free & $\begin{array}{c}\text { State } \\
\text { monopoly }\end{array}$ \\
\hline Arkansas & & 1 & & 1 \\
\hline lowa & 1 & & & 1 \\
\hline Total & 1367 & 54 & 894 & 17 \\
\hline
\end{tabular}


Table 2: Average total assets of banks by type and state

\begin{tabular}{|c|c|c|c|c|}
\hline State & $\begin{array}{c}\text { Chartered/ } \\
\text { no branches }\end{array}$ & $\begin{array}{r}\text { Chartered/ } \\
\text { branches }\end{array}$ & Free & $\begin{array}{c}\text { State } \\
\text { monopoly }\end{array}$ \\
\hline $\begin{array}{l}\text { Alabama } \\
\text { Arkansas } \\
\text { Connecticut } \\
\text { Delaware } \\
\text { District of Columbia }\end{array}$ & $\begin{array}{r}1,985,318 \\
425,833 \\
299,479 \\
751,863\end{array}$ & $\begin{array}{l}1,842,412 \\
2,059,909 \\
1,299,256\end{array}$ & 598,979 & $\begin{array}{l}3,621,097 \\
1,333,256\end{array}$ \\
\hline $\begin{array}{l}\text { Florida } \\
\text { Georgia } \\
\text { Indiana } \\
\text { Illinois } \\
\text { lowa }\end{array}$ & $\begin{array}{r}680,653 \\
633,125 \\
N / A \\
164,435 \\
123,647\end{array}$ & $2,195,438$ & $\begin{array}{l}207,642 \\
191,716\end{array}$ & $\begin{array}{l}7,440,181 \\
2,372,787 \\
1,593,410\end{array}$ \\
\hline $\begin{array}{l}\text { Kansas } \\
\text { Kentucky } \\
\text { Louisiana } \\
\text { Maine } \\
\text { Maryland }\end{array}$ & $\begin{array}{r}61,350 \\
315,371 \\
4,075,187 \\
160,484 \\
697,708\end{array}$ & $1,294,259$ & & $\begin{array}{l}5,440,448 \\
4,809,954\end{array}$ \\
\hline $\begin{array}{l}\text { Massachusetts } \\
\text { Michigan } \\
\text { Minnesota }\end{array}$ & $\begin{array}{l}547,204 \\
249,456\end{array}$ & $1,151,571$ & $\begin{array}{r}1,425,117 \\
78,073 \\
73,160\end{array}$ & \\
\hline $\begin{array}{l}\text { Mississippi } \\
\text { Missouri }\end{array}$ & $\begin{array}{r}1,214,839 \\
958,368\end{array}$ & $\begin{array}{l}6,077,293 \\
2,022,620\end{array}$ & & $\begin{array}{r}\mathrm{N} / \mathrm{A} \\
4,052,698\end{array}$ \\
\hline $\begin{array}{l}\text { Nebraska } \\
\text { New Hampshire } \\
\text { New Jersey } \\
\text { New York } \\
\text { North Carolina }\end{array}$ & $\begin{array}{r}93,504 \\
177,159 \\
344,140 \\
737,715 \\
700,116\end{array}$ & $\begin{array}{r}658,874 \\
2,073,914\end{array}$ & $\begin{array}{l}202,946 \\
602,483\end{array}$ & \\
\hline $\begin{array}{l}\text { Ohio } \\
\text { Pennsylvania } \\
\text { Rhode Island } \\
\text { South Carolina } \\
\text { Tennessee }\end{array}$ & $\begin{array}{r}489,585 \\
683,393 \\
234,109 \\
1,550,403 \\
329,397\end{array}$ & $\begin{array}{l}6,415,354 \\
2,667,187\end{array}$ & 253,400 & \\
\hline $\begin{array}{l}\text { Vermont } \\
\text { Virginia } \\
\text { Wisconsin }\end{array}$ & $\begin{array}{l}189,728 \\
463,931 \\
743,823\end{array}$ & $3,269,163$ & $\begin{array}{l}192,139 \\
140,317\end{array}$ & $\mathrm{~N} / \mathrm{A}$ \\
\hline Average, all banks & 537,752 & $2,808,115$ & 389,887 & $4,024,170$ \\
\hline
\end{tabular}


Table 3: Average capital of banks by type and state

\begin{tabular}{|c|c|c|c|c|}
\hline State & $\begin{array}{c}\text { Chartered/ } \\
\text { no branches }\end{array}$ & $\begin{array}{r}\text { Chartered/ } \\
\text { branches }\end{array}$ & Free & $\begin{array}{c}\text { State } \\
\text { monopoly }\end{array}$ \\
\hline $\begin{array}{l}\text { Alabama } \\
\text { Arkansas } \\
\text { Connecticut } \\
\text { Delaware } \\
\text { District of Columbia }\end{array}$ & $\begin{array}{l}235,643 \\
109,544 \\
362,914\end{array}$ & $\begin{array}{r}1,295,055 \\
1,257,260 \\
645,710\end{array}$ & 100,000 & $\begin{array}{l}1,458,212 \\
1,103,009\end{array}$ \\
\hline $\begin{array}{l}\text { Florida } \\
\text { Georgia } \\
\text { Indiana } \\
\text { Illinois } \\
\text { lowa }\end{array}$ & $\begin{array}{r}418,802 \\
303,992 \\
\mathrm{~N} / \mathrm{A} \\
72,567 \\
100,000\end{array}$ & 824,943 & $\begin{array}{l}86,758 \\
73,055\end{array}$ & $\begin{array}{r}2,411,017 \\
1,228,356 \\
460,450\end{array}$ \\
\hline $\begin{array}{l}\text { Kansas } \\
\text { Kentucky } \\
\text { Louisiana } \\
\text { Maine } \\
\text { Maryland }\end{array}$ & $\begin{array}{r}52,000 \\
179,237 \\
2,111,709 \\
92,351 \\
316,901\end{array}$ & 629,262 & & $\begin{array}{l}2,263,933 \\
1,858,259\end{array}$ \\
\hline $\begin{array}{l}\text { Massachusetts } \\
\text { Michigan } \\
\text { Minnesota }\end{array}$ & $\begin{array}{r}281,159 \\
90,043\end{array}$ & 339,802 & $\begin{array}{r}800,000 \\
33,500 \\
41,157\end{array}$ & \\
\hline $\begin{array}{l}\text { Mississippi } \\
\text { Missouri }\end{array}$ & $\begin{array}{l}813,202 \\
260,210\end{array}$ & $\begin{array}{r}2,641,460 \\
663,655\end{array}$ & & $\begin{array}{r}\mathrm{N} / \mathrm{A} \\
1,370,664\end{array}$ \\
\hline $\begin{array}{l}\text { Nebraska } \\
\text { New Hampshire } \\
\text { New Jersey } \\
\text { New York } \\
\text { North Carolina }\end{array}$ & $\begin{array}{r}37,596 \\
93,447 \\
138,438 \\
301,101 \\
309,820\end{array}$ & $\begin{array}{l}328,442 \\
965,623\end{array}$ & $\begin{array}{r}94,844 \\
228,775\end{array}$ & \\
\hline $\begin{array}{l}\text { Ohio } \\
\text { Pennsylvania } \\
\text { Rhode Island } \\
\text { South Carolina } \\
\text { Tennessee }\end{array}$ & $\begin{array}{l}163,980 \\
268,910 \\
158,977 \\
779,506 \\
108,285\end{array}$ & $\begin{array}{l}1,412,353 \\
1,238,857\end{array}$ & 129,950 & \\
\hline $\begin{array}{l}\text { Vermont } \\
\text { Virginia } \\
\text { Wisconsin }\end{array}$ & $\begin{array}{r}77,630 \\
221,526 \\
100,000\end{array}$ & $1,363,497$ & $\begin{array}{l}80,612 \\
61,979\end{array}$ & $\mathrm{~N} / \mathrm{A}$ \\
\hline Average, all banks & 258,188 & $1,191,634$ & 151,637 & $1,607,130$ \\
\hline
\end{tabular}


Table 4: Average circulation of banks by type and state

\begin{tabular}{|c|c|c|c|c|}
\hline State & $\begin{array}{c}\text { Chartered/ } \\
\text { no branches }\end{array}$ & $\begin{array}{r}\text { Chartered/ } \\
\text { branches }\end{array}$ & Free & $\begin{array}{c}\text { State } \\
\text { monopoly }\end{array}$ \\
\hline $\begin{array}{l}\text { Alabama } \\
\text { Arkansas } \\
\text { Connecticut } \\
\text { Delaware } \\
\text { District of Columbia }\end{array}$ & $\begin{array}{l}695,434 \\
108,575 \\
105,789 \\
118,791\end{array}$ & $\begin{array}{l}318,543 \\
458,028 \\
351,511\end{array}$ & 84,437 & $\begin{array}{r}1,031,959 \\
144,875\end{array}$ \\
\hline $\begin{array}{l}\text { Florida } \\
\text { Georgia } \\
\text { Indiana } \\
\text { Illinois } \\
\text { lowa }\end{array}$ & $\begin{array}{r}89,657 \\
199,663 \\
N / A \\
69,585 \\
10,990\end{array}$ & 391,792 & $\begin{array}{r}80,373 \\
100,426\end{array}$ & $\begin{array}{r}3,407,002 \\
834,925 \\
563,836\end{array}$ \\
\hline $\begin{array}{l}\text { Kansas } \\
\text { Kentucky } \\
\text { Louisiana } \\
\text { Maine } \\
\text { Maryland }\end{array}$ & $\begin{array}{r}5,580 \\
90,774 \\
433,838 \\
54,093 \\
117,977\end{array}$ & $1,358,136$ & & $\begin{array}{r}1,537,447 \\
768,249\end{array}$ \\
\hline $\begin{array}{l}\text { Massachusetts } \\
\text { Michigan } \\
\text { Minnesota }\end{array}$ & $\begin{array}{r}110,872 \\
81,319\end{array}$ & 214,607 & $\begin{array}{r}133,505 \\
27,649 \\
20,086\end{array}$ & \\
\hline $\begin{array}{l}\text { Mississippi } \\
\text { Missouri }\end{array}$ & $\begin{array}{l}241,385 \\
388,585\end{array}$ & $\begin{array}{r}1,044,784 \\
617,701\end{array}$ & & $\begin{array}{r}\mathrm{N} / \mathrm{A} \\
1,273,605\end{array}$ \\
\hline $\begin{array}{l}\text { Nebraska } \\
\text { New Hampshire } \\
\text { New Jersey } \\
\text { New York } \\
\text { North Carolina }\end{array}$ & $\begin{array}{r}39,977 \\
59,533 \\
74,674 \\
156,900 \\
301,168\end{array}$ & $\begin{array}{l}200,560 \\
720,830\end{array}$ & $\begin{array}{l}64,630 \\
90,536\end{array}$ & \\
\hline $\begin{array}{l}\text { Ohio } \\
\text { Pennsylvania } \\
\text { Rhode Island } \\
\text { South Carolina } \\
\text { Tennessee }\end{array}$ & $\begin{array}{r}175,112 \\
167,286 \\
36,053 \\
430,944 \\
102,874\end{array}$ & $\begin{array}{r}1,196,781 \\
761,167\end{array}$ & 111,616 & \\
\hline $\begin{array}{l}\text { Vermont } \\
\text { Virginia } \\
\text { Wisconsin }\end{array}$ & $\begin{array}{r}90,587 \\
141,302 \\
33,898\end{array}$ & $1,094,037$ & $\begin{array}{l}90,745 \\
39,766\end{array}$ & $\mathrm{~N} / \mathrm{A}$ \\
\hline Average, all banks & 125,309 & 767,138 & 77,980 & $1,348,016$ \\
\hline
\end{tabular}




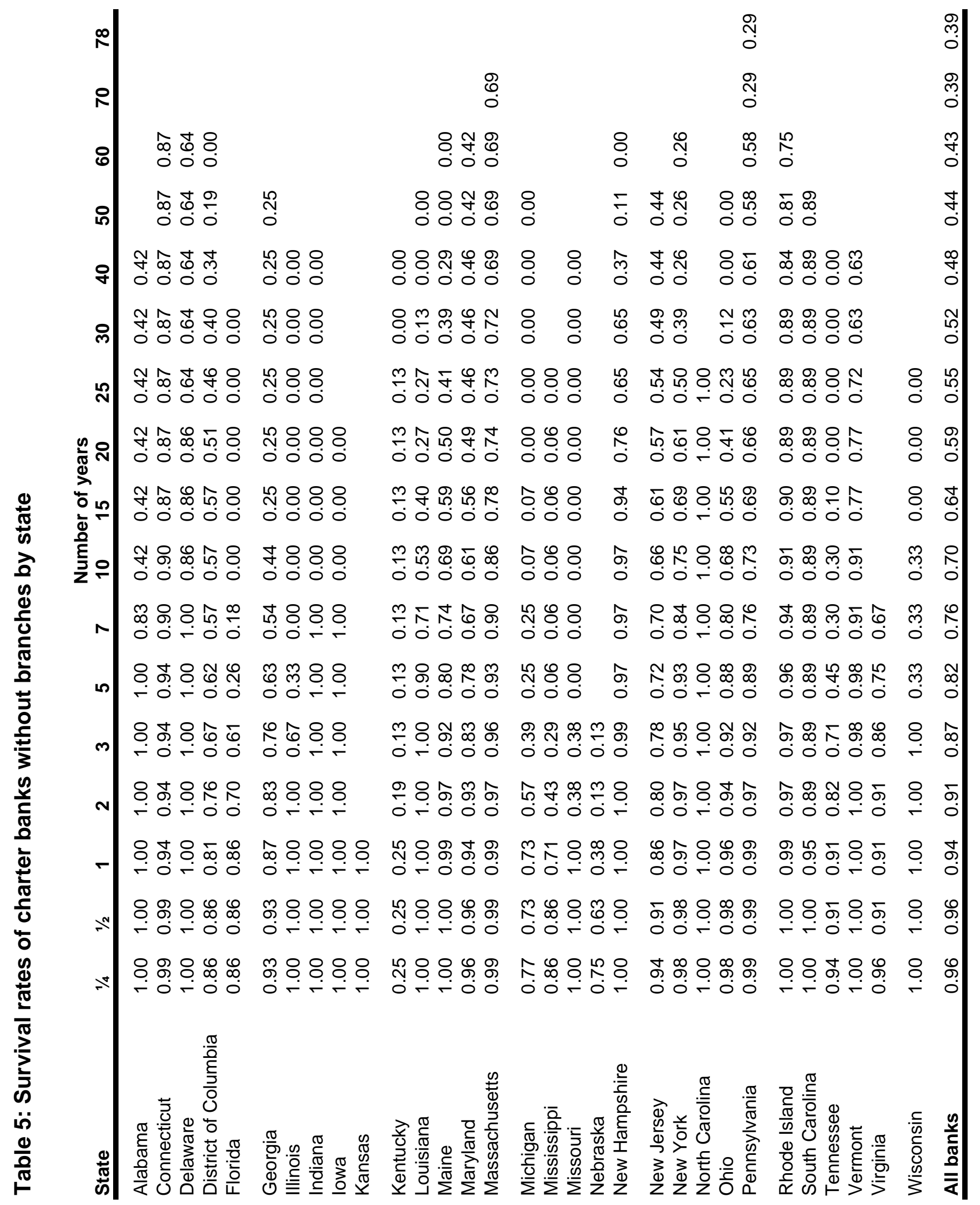




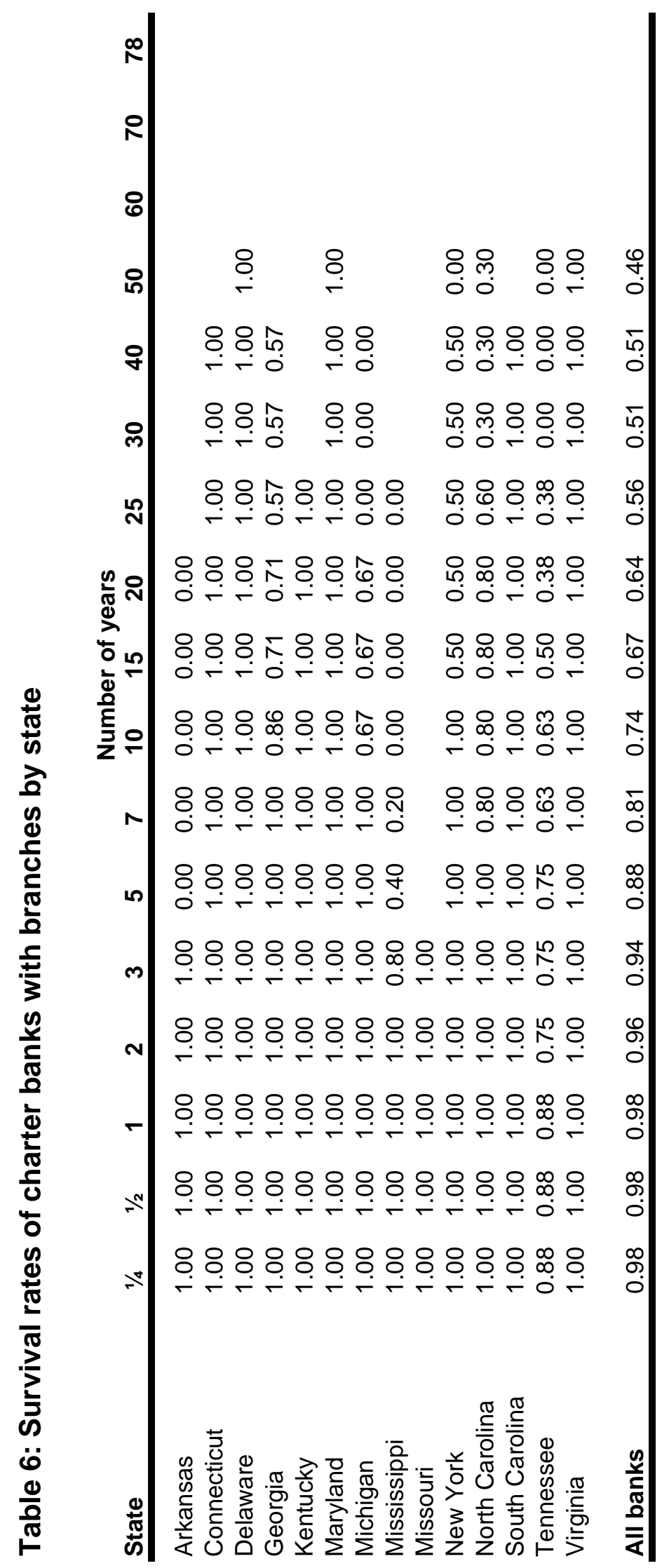




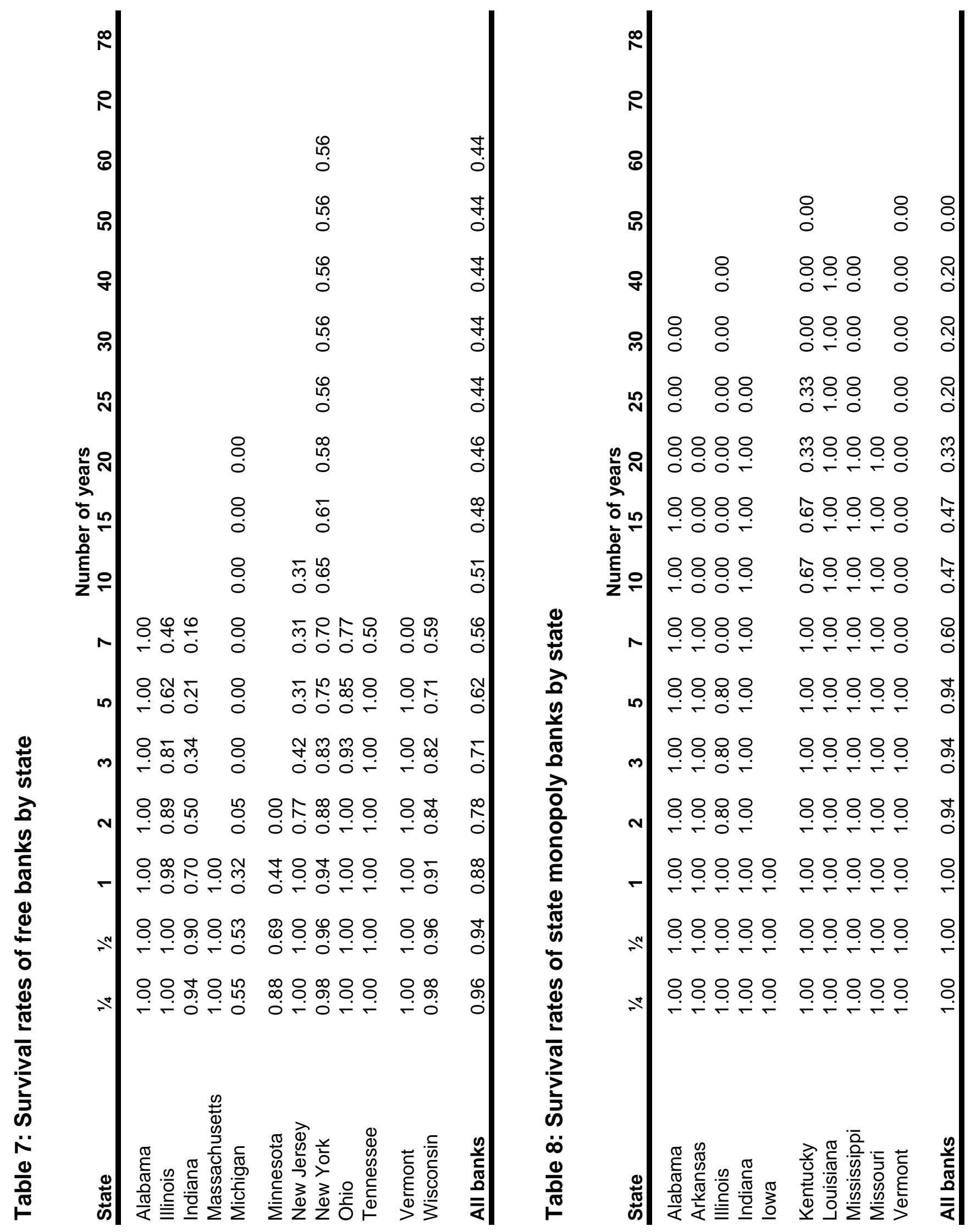


Table 9: Disposition of charter banks without branches by state

\begin{tabular}{|c|c|c|c|c|c|c|c|c|c|}
\hline State & Total & Good & Closed & Failed & No Info & Other & $\begin{array}{c}\text { Good } \\
\text { (\%) }\end{array}$ & $\begin{array}{l}\text { Failed } \\
(\%)\end{array}$ & $\begin{array}{c}\text { Failed/ } \\
\text { nongood } \\
(\%)\end{array}$ \\
\hline Delaware & 10 & 8 & 1 & 0 & 0 & 1 & 80.0 & 0.0 & 0.0 \\
\hline Kansas & 1 & 1 & 0 & 0 & 0 & 0 & 100.0 & 0.0 & \\
\hline lowa & 1 & 0 & 1 & 0 & 0 & 0 & 0.0 & 0.0 & 0.0 \\
\hline North Carolina & 11 & 11 & 0 & 0 & 0 & 0 & 100.0 & 0.0 & \\
\hline New Hampshire & 69 & 51 & 15 & 3 & 0 & 0 & 73.9 & 4.3 & 16.7 \\
\hline Massachusetts & 225 & 174 & 37 & 12 & 2 & 0 & 77.3 & 6.2 & 27.5 \\
\hline Connecticut & 82 & 73 & 1 & 7 & 0 & 1 & 89.0 & 8.5 & 77.8 \\
\hline Vermont & 49 & 40 & 4 & 4 & 1 & 0 & 81.6 & 10.2 & 55.6 \\
\hline South Carolina & 19 & 17 & 0 & 2 & 0 & 0 & 89.5 & 10.5 & 100.0 \\
\hline Rhode Island & 104 & 90 & 3 & 11 & 0 & 0 & 86.5 & 10.6 & 78.6 \\
\hline New Jersey & 70 & 40 & 21 & 8 & 1 & 0 & 57.1 & 12.9 & 30.0 \\
\hline Maine & 124 & 69 & 36 & 19 & 0 & 0 & 55.6 & 15.3 & 34.5 \\
\hline Louisiana & 24 & 10 & 10 & 1 & 3 & 0 & 41.7 & 16.7 & 28.6 \\
\hline Virginia & 23 & 17 & 2 & 4 & 0 & 0 & 73.9 & 17.4 & 66.7 \\
\hline Alabama & 10 & 7 & 1 & 2 & 0 & 0 & 70.0 & 20.0 & 66.7 \\
\hline Missouri & 4 & 1 & 2 & 1 & 0 & 0 & 25.0 & 25.0 & 33.3 \\
\hline Tennessee & 34 & 10 & 15 & 8 & 1 & 0 & 29.4 & 26.5 & 37.5 \\
\hline Pennsylvania & 114 & 80 & 3 & 21 & 10 & 0 & 70.2 & 27.2 & 91.2 \\
\hline Maryland & 54 & 27 & 11 & 14 & 2 & 0 & 50.0 & 29.6 & 59.3 \\
\hline Ohio & 110 & 50 & 27 & 32 & 1 & 0 & 45.5 & 30.0 & 55.0 \\
\hline New York & 61 & 27 & 12 & 21 & 1 & 0 & 44.3 & 36.1 & 64.7 \\
\hline District of Columbia & 21 & 6 & 4 & 6 & 2 & 3 & 28.6 & 38.1 & 53.3 \\
\hline Georgia & 46 & 21 & 5 & 16 & 3 & 1 & 45.7 & 41.3 & 76.0 \\
\hline Indiana & 2 & 0 & 1 & 1 & 0 & 0 & 0.0 & 50.0 & 50.0 \\
\hline Florida & 14 & 2 & 3 & 8 & 0 & 1 & 14.3 & 57.1 & 66.7 \\
\hline Illinois & 3 & 0 & 1 & 2 & 0 & 0 & 0.0 & 66.7 & 66.7 \\
\hline Wisconsin & 3 & 1 & 0 & 2 & 0 & 0 & 33.3 & 66.7 & 100.0 \\
\hline Michigan & 30 & 3 & 5 & 21 & 1 & 0 & 10.0 & 73.3 & 81.5 \\
\hline Kentucky & 20 & 3 & 0 & 15 & 2 & 0 & 15.0 & 85.0 & 100.0 \\
\hline Mississippi & 21 & 2 & 0 & 17 & 1 & 1 & 9.5 & 85.7 & 94.7 \\
\hline Nebraska & 8 & 0 & 1 & 5 & 2 & 0 & 0.0 & 87.5 & 87.5 \\
\hline All banks & 1367 & 841 & 222 & 263 & 33 & 8 & 61.5 & 21.7 & 56.3 \\
\hline
\end{tabular}


Table 10: Disposition of charter banks with branches by state

\begin{tabular}{|c|c|c|c|c|c|c|c|c|c|}
\hline State & Total & Good & Closed & Failed & No Info & Other & $\begin{array}{c}\text { Good } \\
\text { (\%) }\end{array}$ & $\begin{array}{c}\text { Failed } \\
(\%)\end{array}$ & $\begin{array}{c}\text { Failed/ } \\
\text { nongood } \\
(\%)\end{array}$ \\
\hline Arkansas & 1 & 0 & 1 & 0 & 0 & 0 & 0.0 & 0.0 & 0.0 \\
\hline Connecticut & 1 & 1 & 0 & 0 & 0 & 0 & 100.0 & 0.0 & \\
\hline Delaware & 1 & 1 & 0 & 0 & 0 & 0 & 100.0 & 0.0 & \\
\hline Kentucky & 5 & 5 & 0 & 0 & 0 & 0 & 100.0 & 0.0 & \\
\hline Maryland & 1 & 1 & 0 & 0 & 0 & 0 & 100.0 & 0.0 & \\
\hline Michigan & 3 & 1 & 2 & 0 & 0 & 0 & 33.3 & 0.0 & 0.0 \\
\hline Missouri & 7 & 7 & 0 & 0 & 0 & 0 & 100.0 & 0.0 & \\
\hline South Carolina & 1 & 1 & 0 & 0 & 0 & 0 & 100.0 & 0.0 & \\
\hline Virginia & 7 & 7 & 0 & 0 & 0 & 0 & 100.0 & 0.0 & \\
\hline North Carolina & 5 & 2 & 2 & 1 & 0 & 0 & 40.0 & 20.0 & 33.3 \\
\hline Georgia & 7 & 4 & 1 & 2 & 0 & 0 & 57.1 & 28.6 & 66.7 \\
\hline New York & 2 & 0 & 1 & 1 & 0 & 0 & 0.0 & 50.0 & 50.0 \\
\hline Tennessee & 8 & 3 & 1 & 4 & 0 & 0 & 37.5 & 50.0 & 80.0 \\
\hline Mississippi & 5 & 0 & 1 & 4 & 0 & 0 & 0.0 & 80.0 & 80.0 \\
\hline All banks & 54 & 33 & 9 & 12 & 0 & 0 & 61.1 & 22.2 & 57.1 \\
\hline
\end{tabular}


Table 11: Disposition of free banks by state

\begin{tabular}{|c|c|c|c|c|c|c|c|c|c|}
\hline State & Total & Good & Closed & Failed & No Info & Other & $\begin{array}{c}\text { Good } \\
(\%)\end{array}$ & $\begin{array}{c}\text { Failed } \\
(\%)\end{array}$ & $\begin{array}{c}\text { Failed } / \\
\text { nongood } \\
(\%)\end{array}$ \\
\hline Alabama & 1 & 0 & 1 & 0 & 0 & 0 & 0.0 & 0.0 & 0.0 \\
\hline Massachusetts & 4 & 4 & 0 & 0 & 0 & 0 & 100.0 & 0.0 & \\
\hline Wisconsin & 143 & 110 & 30 & 1 & 2 & 0 & 76.9 & 2.1 & 9.1 \\
\hline Illinois & 131 & 100 & 23 & 8 & 0 & 0 & 76.3 & 6.1 & 25.8 \\
\hline New Jersey & 26 & 8 & 16 & 2 & 0 & 0 & 30.8 & 7.7 & 11.1 \\
\hline New York & 423 & 278 & 107 & 33 & 2 & 3 & 65.7 & 8.3 & 24.1 \\
\hline Ohio & 14 & 10 & 1 & 1 & 2 & 0 & 71.4 & 21.4 & 75.0 \\
\hline Indiana & 96 & 17 & 36 & 42 & 1 & 0 & 17.7 & 44.8 & 54.4 \\
\hline Tennessee & 2 & 0 & 1 & 1 & 0 & 0 & 0.0 & 50.0 & 50.0 \\
\hline Minnesota & 16 & 5 & 2 & 9 & 0 & 0 & 31.3 & 56.3 & 81.8 \\
\hline Michigan & 38 & 0 & 3 & 34 & 1 & 0 & 0.0 & 92.1 & 92.1 \\
\hline Vermont & 1 & 0 & 0 & 1 & 0 & 0 & 0.0 & 100.0 & 100.0 \\
\hline All banks & 895 & 532 & 220 & 132 & 8 & 3 & 59.4 & 15.6 & 38.6 \\
\hline
\end{tabular}

Table 12: Disposition of state monopoly banks by state

\begin{tabular}{|c|c|c|c|c|c|c|c|c|c|}
\hline State & Total & Good & Closed & Failed & No Info & Other & $\begin{array}{c}\text { Good } \\
(\%)\end{array}$ & $\begin{array}{c}\text { Failed } \\
(\%)\end{array}$ & $\begin{array}{c}\text { Failed/ } \\
\text { nongood } \\
(\%)\end{array}$ \\
\hline Alabama & 1 & 0 & 1 & 0 & 0 & 0 & 0.0 & 0.0 & 0.0 \\
\hline Arkansas & 1 & 0 & 1 & 0 & 0 & 0 & 0.0 & 0.0 & 0.0 \\
\hline Indiana & 2 & 1 & 1 & 0 & 0 & 0 & 50.0 & 0.0 & 0.0 \\
\hline lowa & 1 & 1 & 0 & 0 & 0 & 0 & 100.0 & 0.0 & \\
\hline Louisiana & 1 & 1 & 0 & 0 & 0 & 0 & 100.0 & 0.0 & \\
\hline Mississippi & 1 & 0 & 1 & 0 & 0 & 0 & 0.0 & 0.0 & 0.0 \\
\hline Missouri & 1 & 1 & 0 & 0 & 0 & 0 & 100.0 & 0.0 & \\
\hline Kentucky & 3 & 1 & 1 & 1 & 0 & 0 & 33.3 & 33.3 & 50.0 \\
\hline Illinois & 5 & 0 & 2 & 3 & 0 & 0 & 0.0 & 60.0 & 60.0 \\
\hline Vermont & 1 & 0 & 0 & 1 & 0 & 0 & 0.0 & 100.0 & 100.0 \\
\hline All banks & 17 & 5 & 7 & 5 & 0 & 0 & 29.4 & 29.4 & 41.7 \\
\hline
\end{tabular}


Table 13: Estimated noteholder losses by bank type

Losses based on redemption information

\begin{tabular}{|c|c|c|c|}
\hline $\begin{array}{l}\text { Chartered/ } \\
\text { no branches }\end{array}$ & $\begin{array}{c}\text { Charteredl } \\
\text { branches }\end{array}$ & Free & $\begin{array}{l}\text { State } \\
\text { monopoly }\end{array}$ \\
\hline 23 & & 60 & \\
\hline 73,023 & & 75,153 & \\
\hline 30,331 & & 17,370 & \\
\hline 0.42 & & 0.23 & \\
\hline
\end{tabular}

Losses based on New York discounts

Number of banks

Average circulation/bank (\$)

Average loss/bank (\$)

Average loss/dollar of notes (\$)

0.42

17,370

\begin{tabular}{lrrrr} 
& $\begin{array}{c}\text { Chartered/ } \\
\text { no branches }\end{array}$ & $\begin{array}{c}\text { Chartered } \\
\text { branches }\end{array}$ & Free & $\begin{array}{r}\text { State } \\
\text { monopoly }\end{array}$ \\
\cline { 2 - 5 } Number of banks & 117 & 5 & 78 & 2 \\
Average circulation/bank (\$) & 137,452 & 267,470 & 86,402 & 306,856 \\
Average loss/bank (\$) & 67,890 & 197,363 & 29,763 & 113,149 \\
Average loss/dollar of notes (\$) & 0.49 & 0.74 & 0.34 & 0.37 \\
Number of banks & 104 & 3 & 69 & 2 \\
Average circulation/bank (\$) & 143,754 & 178,107 & 89,602 & 306,856 \\
Average loss/bank (\$) & 65,497 & 61,261 & 25,574 & 113,149 \\
Average loss/dollar of notes (\$) & 0.46 & 0.34 & 0.29 & 0.37
\end{tabular}

Losses based on Philadelphia discounts

Number of banks

Average circulation/bank (\$)

Average loss/bank (\$)

Average loss/dollar of notes (\$)

Number of banks

Average circulation/bank (\$)

Average loss/bank (\$)

Average loss/dollar of notes (\$)

\begin{tabular}{|c|c|c|c|}
\hline $\begin{array}{l}\text { Charteredl } \\
\text { no branches }\end{array}$ & $\begin{array}{l}\text { Chartered/ } \\
\text { branches }\end{array}$ & Free & $\begin{array}{l}\text { State } \\
\text { monopoly }\end{array}$ \\
\hline 115 & 5 & 77 & 2 \\
\hline 137,658 & 762,948 & 72,185 & 306,856 \\
\hline 72,531 & 418,821 & 24,589 & 76,704 \\
\hline 0.53 & 0.55 & 0.34 & 0.25 \\
\hline 91 & 3 & 71 & 2 \\
\hline 144,214 & $1,003,904$ & 71,763 & 306,856 \\
\hline 61,910 & 430,358 & 20,145 & 76,704 \\
\hline 0.43 & 0.43 & 0.28 & 0.25 \\
\hline
\end{tabular}


Figure 1: Survival probabilities by bank type
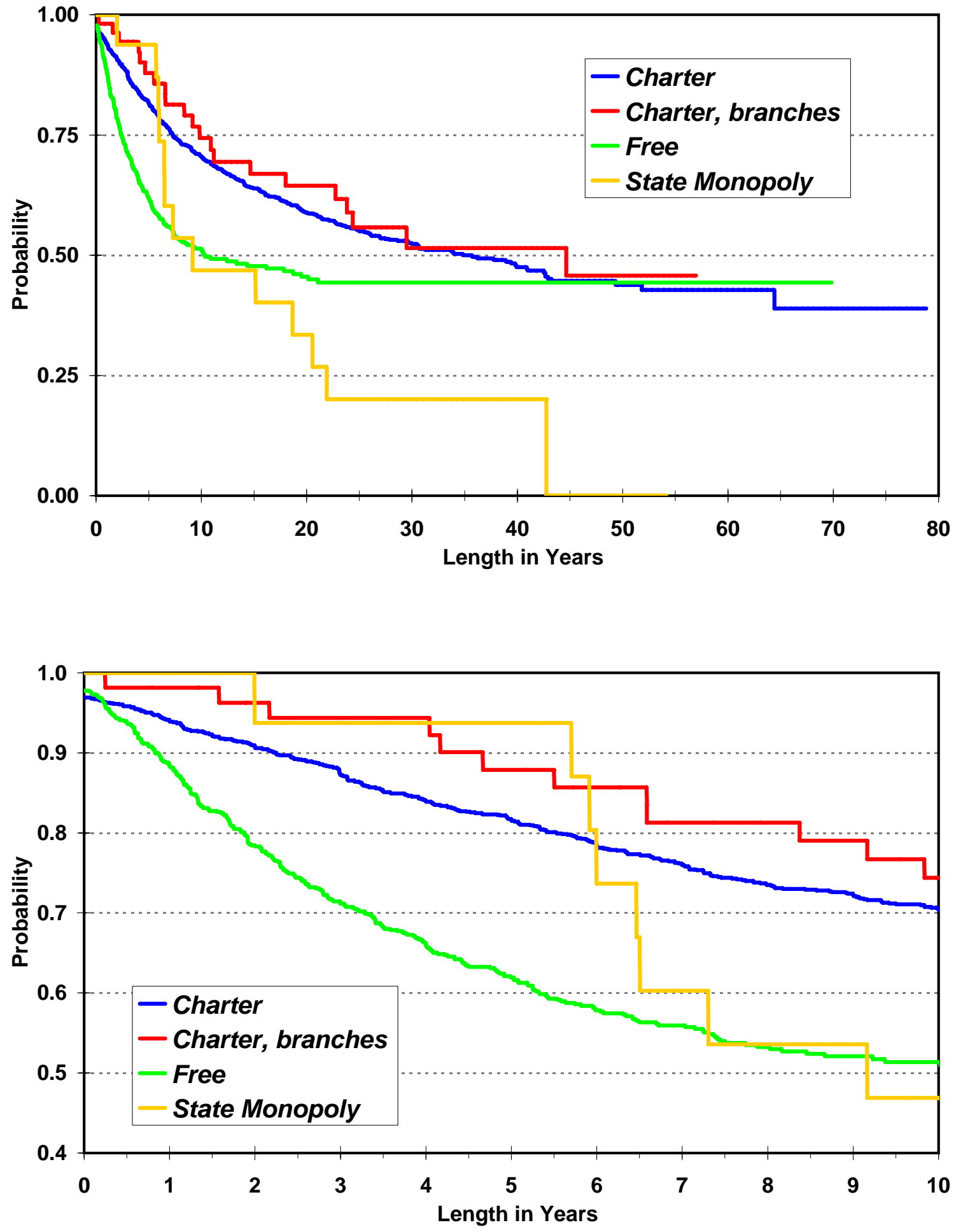